\title{
PENGARUH VEGETASI TERHADAP DINAMIKA PERKEMBANGAN GUMUK PASIR DI PESISIR PARANGKUSUMO
}

\author{
Oleh: \\ Fahad Nuraini ${ }^{1}$, Sunarto ${ }^{2}$, Langgeng Wahyu Santosa ${ }^{2}$ \\ ${ }^{1}$ Mahasiswa S2 Geografi, Fakultas Geografi, Universitas Gadjah Mada, Yogyakarta \\ ${ }^{2}$ Staf Pengajar Fakultas Geografi, Universitas Gadjah Mada, Yogyakarta \\ fahadnuraini@yahoo.co.id.
}

\begin{abstract}
Abstrak
Penelitian ini dilakukan di kawasan gumuk pasir aktif pada lorong angin alami Pesisir Parangkusumo dengan tujuan mengetahui pengaruh tutupan lahan vegetasi pada bentuklahan gumuk pasir di Pesisir Parangkusumo, sedangkan perkembangan normal gumuk pasir terjadi tanpa tutupan. Penelitian ini merupakan penelitian eksploratif-survey dengan maksud mengungkapkan pengaruh vegetasi terhadap perkembangan bentuklahan, dengan fokus peran vegetasi sebagai ecological engineering. Penelitian dilakukan dengan mengidentifikasi pengaruh vegetasi dalam perkembangan gumuk pasir dilihat dari faktor pembentuk yaitu proses deflasi dan juga identifikasi morfologi. Hasil penelitian menunjukkan pada area gumuk pasir terdapat beberapa tipe vegetasi penutup yaitu vegetasi insitu dan eksitu. Vegetasi insitu merupakan vegetasi alami gumuk pasir yaitu pandan, rumput teki, dan siwalan; sedangkan vegetasi eksitu berupa penghutanan dengan vegetasi cemara dan akasia. Kedua tipe vegetasi tersebut berdampak terhadap dinamika perkembangan gumuk pasir yang terjadi secara perlahan dalam kurun waktu tertentu seiring dengan pertumbuhan vegetasi. Efek dari vegetasi menghasilkan gangguan gelembur permukaan sampai dengan perkembangan lubang deflasi sebagai indikator kerusakan gumuk pasir.
\end{abstract}

Kata kunci: Gumuk Pasir, Vegetasi, Parangkusumo

\begin{abstract}
This research was conducted in the area of active sand dunes Parangkusumo aiming at investigating the effects of land cover vegetation on the landforms of sand dunes in Parangkusumo coastal areas. Normally, the development of sand dune occurs without land cover. This research is an exploratory-survey, intending to reveal the influence of vegetation on the development of landforms, with a focus on the role of vegetation as ecological engineering. The research was carried out by identifying the influences of vegetation in the development of sand dune viewed from the determining factors namely the process of deflation and also the identification of morphology. The results show that there are several types of vegetation cover i.e. vegetation insitu and exsitu found in sand dune areas. Insitu is a natural sand dune vegetation which include papyrus, sedges, and siwalan; whereas exsitu includes the reforestation with pine and acacia vegetation. Both types of vegetation influence the dynamics of sand dunes which occurs slowly in a specified period along with the growth of vegetation. The effects of vegetation is producing disruption of the ripple until development of blowout as an indicator of sand dune damage.
\end{abstract}

Keywords: Sand Dune, Vegetation, Parangkusumo 


\section{PENDAHULUAN}

Gumuk pasir di wilayah pesisir Parangkusumo merupakan satu-satunya gumuk pasir yang memiliki bentuk khas berupa tipe barkhan. Verstappen (1957 dalam Hesp, 2008) menjelaskan bahwa, gumuk pasir di wilayah pesisir Parangkusumo merupakan gumuk pasir tropis yang memiliki ukuran terbesar, dengan ketinggian dapat mencapai 15 meter, dan terbentuk oleh adanya energi angin yang kuat. Faktor lain yang mempengaruhi pembentukan gumuk pasir adalah pantai dengan tipe dissipative dan intermediate. Pembentukan gumuk pasir di wilayah pesisir Parangkusumo juga dipengaruhi oleh adanya kondisi lokal berupa angin monsun timur. Sunarto (2014), menyimpulkan bahwa ada sembilan faktor pembentuk gumuk pasir di kepesisiran yang meliputi: 1) adanya tiupan angin dari laut menuju ke pantai; 2) adanya koridor angin (wind corridor) atau lorong angin alami (wind tunnel); 3) adanya pasokan material pasir; 4) material berbentuk lepas-lepas; 5) morfologi gisik; 6) kelerengan gisik; 7) lebar gisik; 8) julat pasut; 9) pengahalang angin. (Gambar 1)

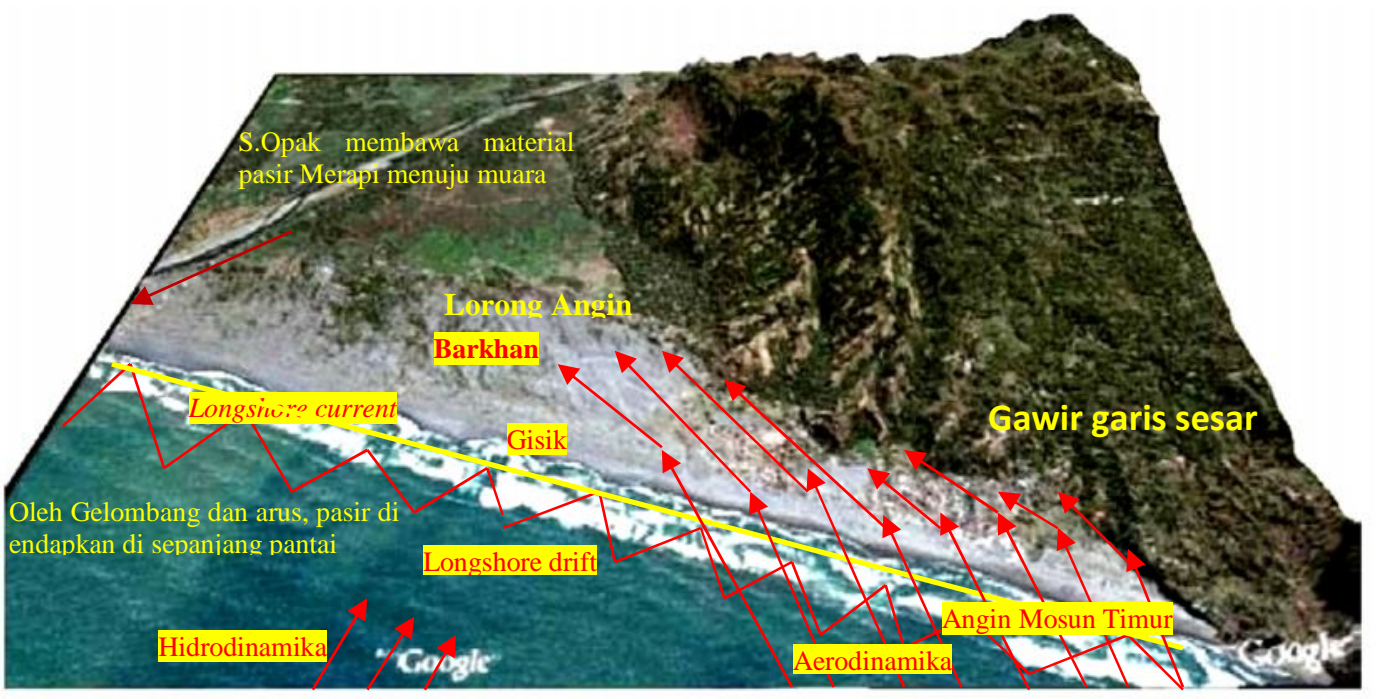

Gambar 1. Ilustrasi Proses Pembentukan Gumuk Pasir yang di Dukung oleh Lingkungan Kepesisiran Parangkusumo (Sumber: Nuraini, 2016)

Selain faktor pembentukan gumuk pasir yang unik dan komplek, nilai keunikan gumuk pasir juga terdapat pada salah satu fungsi penting gumuk pasir yaitu sebagai pelindung atau peredam gelombang tsunami. Walaupun memiliki keunikan bentuklahan dan fungsi lingkungan, Sunarto (2014) mengungkapkan bahwa gumuk pasir di wilayah pesisir Parangkusumo telah terancam oleh kegiatan agrogenik (penghutanan, dan pertanian) dan urbanogenik (ekspansi permukiman) pada area gumuk pasir aktif. Pina dkk (2002) juga mengungkapkan bahwa adanya penghutanan, alih fungsi lahan, dan permukiman merupakan faktor-faktor yang mengakibatkan kerusakan gumuk pasir. Lebih lanjut Goldsmith (1985) mengemukakan bahwa vegetasi mempunyai pengaruh terhadap dinamika perubahan gumuk pasir. 
Kidd (2001) menjelaskan bahwa vegetasi penutup merupakan faktor yang sangat berpengaruh terhadap perubahan morfologi gumuk pasir. Hal ini dikarenakan kecepatan angin akan tertahan oleh vegetasi tersebut, sehingga material deposisi terperangkap pada muka vegetasi dan angin mengalami percepataan penurunan (loncatan angin) membentuk angin turbulen di belakang vegetasi. Turbulensi angin tersebut bersifat menggerus, sehingga terbentuk lubang-lubang deflasi di belakang vegetasi. Tanpa adanya vegetasi penghalang pasir dengan mudah berpindah oleh tenaga angin. Namun karena adanya vegetasi tersebut, maka dapat mengganggu keseimbangan dinamika alami dalam pembentukan gumuk pada musim kemarau. Lubang deflasi (blowout) yang terbentuk semakin lama akan semakin dalam dan lebar, sehingga dampaknya dapat mengakibatkan runtuhnya dinding gumuk, yang pada akhirnya pembentukan gumuk pasir akan terhenti.

Dari latar belakang diatas menunjukkan bahwa gumuk pasir merupakan bentuk lahan yang memiliki dinamika perkembangan yang sangat rapuh sehingga perkembangan normal gumuk pasir hanya akan terjadi bila lingkungan mendukung. Perubahan kondisi ekologi terutama perubahan akibat interaksi manusia dengan lingkungan yang terus berkembang dari waktu ke waktu memiliki efek terhadap dinamika perkembangan gumuk pasir. Penelitian ini bertujuan untuk mengetahui pengaruh vegetasi terhadap dinamika perkembangan gumuk pasir yang terdapat di Pesisir Parangkusumo. Vegetasi yang terdapat pada gumuk pasir Parangkusumo dapat berupa vegetasi alami maupun vegetasi hasil penghutanan yang dilakukan pada area gumuk pasir aktif.

\section{METODE}

Penelitian ini dilaksanakan pada area lorong angin alami gumuk pasir di Pesisir Parangkusumo. Lorong angin alami merupakan area yang terdapat gumuk pasir aktif dengan tipe gumuk pasir barkhan. Luasan total wilayah lorong angin seluas $432,75 \mathrm{~m}^{2}$ dengan rata-rata lebar lorong angin 610,77 m dan panjang $875 \mathrm{~m}$ (Sunarto, 2014). Daerah penelitian dari seluruh luasan wilayah tersebut dibatasi pada wilayah seluas 22 ha. Penelitian ini merupakan penelitian eksploratif dengan menggunakan metode survei. Pengambilan sampel dengan dilakukan dengan cara sistematik sampling. Petunjuk untuk survei lapangan menggunakan peta tentatif berdasarkan sisitem grid dengan luasan $10 \times 10 \mathrm{~m}^{2}$. Setelah hasil survei lapangan diperoleh kemudian dibuat zonasi berdasarkan variasi dari kemunculan vegetasi, jenis, variasi kerapatan dan ketinggian vegetasi. Data yang telah diperoleh selanjutnya dianalisis secara deskriptif dengan pendekatan induktif, memperhatikan hubungan sebab akibat antara kondisi vegetasi dengan kondisi morfologi gumuk pasir, gelembur pasir, dan lubang deflasi yang terbentuk

\section{HASIL DAN PEMBAHASAN}

\section{Bentuklahan Gumuk Pasir pada Pesisir Parangkusumo}

Kondisi morfografi daerah penelitian ditunjukkan oleh adanya berbagai bentuk tipe gumuk pasir dengan kondisi morfometri yang berbeda. dari hasil pengamatan lapangan dapat di identifikasi beberapa tipe gumuk pasir yang terdapat di Pesisir Parangkusumo di antaranya tipe lidah, tipe memanjang, tipe melintang, tipe nebkha, dan tipe barkhan. 
Identifikasi tipe tersebut sama dengan kehadiran gumuk pasir pada tahun 2000, namun yang berbeda adalah jumlah gumuk pasir. Tipe gumuk pasir di daerah penelitian ditunjukkan oleh Tabel 1.

Tabel 1. Tipe dan Morfometri Gumuk Pasir di Daerah Penelitian Tahun 2014

\begin{tabular}{|c|l|l|c|c|c|c|c|c|c|}
\hline \multicolumn{2}{|c|}{ Koordinat } & Tipe Gumuk & $\begin{array}{c}\text { Panjang } \\
\text { Pasir }\end{array}$ & $\begin{array}{c}\text { Lebar } \\
(\mathrm{m})\end{array}$ & $\begin{array}{c}\text { Tinggi } \\
(\mathrm{m})\end{array}$ & $\begin{array}{c}\text { Sudut } \\
\text { Depan }\end{array}$ & $\begin{array}{c}\text { Sudut } \\
\text { Belakang }\end{array}$ & $\begin{array}{c}\text { Panjang } \\
\text { Tanduk }\end{array}$ & $\begin{array}{c}\text { Jumlah } \\
\text { di Lokasi }\end{array}$ \\
\hline 424792 & 9113857 & Lidah & 55 & 15 & 1 & $40^{\circ}$ & $29^{\circ}$ & & 2 \\
\hline 424851 & 9113775 & Memanjang & 33 & 15 & 1,5 & $20^{\circ}$ & $14^{\circ}$ & & 4 \\
\hline 424902 & 9113675 & $\begin{array}{l}\text { Barkhan } \\
\text { (rusak) }\end{array}$ & 60 & 40 & 3 & $40^{\circ}$ & $22^{\circ}$ & $1 \mathrm{~m}$ & 1 \\
\hline 424862 & 9113694 & Melintang & 90 & 30 & 2,5 & $52^{\circ}$ & $10^{\circ}$ & & 3 \\
\hline 424797 & 9113687 & Nebkha & 100 & 40 & 4 & $68^{\circ}$ & $40^{\circ}$ & & 1 \\
\hline 424653 & 9113817 & Barkhan & 90 & 71 & 2 & $25^{\circ}$ & $15^{\circ}$ & 8,20 & 1 \\
\hline
\end{tabular}

Sumber: Nuraini (2016)

\section{Perkembangan Vegetasi pada Gumuk Pasir di Pesisir Parangkusumo}

Gumuk pasir aktif di lorong angin merupakan gumuk pasir yang akan tumbuh bila memiliki lingkungan yang tanpa penghalang. Berdasarkan hasil paparan pemerintah daerah dan masyarakat setempat dijelaskan bahwa daerah gumuk pasir Parangtritis sampai dengan depok pada tahun 1970an merupakan daerah yang dikenal sebagai oro-oro atau daerah tenggar tanpa ada tanaman eksitu maupun bangunan. Setelah tahun 1980an mulai diadakan penanaman yang dimulai dari bagian barat di Pesisir Depok, kemudian pada tahun 1990an, 2000, 2010 dan 2012 diadakan penghutanan di daerah pesisir Parangkusumo.

Lebih lanjut berdasarkan hasil wawancara dengan masyarakat di daerah penelitian diketahui bahwa pemukiman sudah dilakukan sejak 13 tahun yang lalu. Sebelum diadakan penghijauan, masyarakat bertahan hidup dari bahaya deflasi namun setelah ada penanaman cemara dan akasia masyarakat merasa nyaman karena pasir tidak lagi masuk rumah dan juga tercipta mikroiklim yang sejuk. Untuk memenuhi kebutuhan sehari-hari masayarakat sekitar memanfaatkan lahan pasir untuk bertani holtikultura berupa sayuran dan buah. Selain itu juga melakukan kegiatan usaha wisata dengan menyediakan fasilitas parkir dan warung. Hutan cemara dan akasia dimanfaatkan batangnya untuk kayu bakar.

Hasil survei lingkungan di pesisir Parangkusumo menunjukkan bahwa pada lahan gumuk pasir di daerah Parangkusumo telah mengalami campur tangan manusia dalam pengelolaannya. Kondisi ini ditunjukkan oleh berkembangnya pemukiman di sekitar jalan penghubung antara Parangtritis-Depok, selain itu juga terdapat vegetasi eksitu seperti cemara udang (Casuarina equisetifolia) dan akasia (Accacia longifolia). Selain tanaman juga terdapat rumah (Gambar 1). Kondisi ini dapat menghambat pertumbuhan gumuk pasir. Winarni dkk (2012) mengemukakan bahwa vegetasi yang tumbuh di wilayah pesisir dapat mempengaruhi laju kecepatan angin di belakangnnya maksimal sejauh 25 kali tinggi tanaman. Sedangkan angin merupakan salah satu faktor penting dalam pembentukan gumuk pasir 
Sebaran vegetasi pada sand dune membentuk blok-blok sesuai dengan periode waktu tanam. Blok pertama terdapat pada zona satu dan dua. Pada zona ini terdapat vegetasi eksitu berupa cemara udang dan akasia dengan ketinggian tiga meter, jarak tanam lima meter, serta kanopi rapat dengan tajuk daun saling berhimpit. Vegetasi dan bangunan ini menempati kaki barkhan dan juga memanjang ke arah timur. Blok yang kedua terdapat pada zona tiga. Pada zona ini terdapat vegetasi eksitu berupa cemara dengan ketinggian tiga meter, memiliki kerapatan sangat tinggi, dan antar tajuk saling berhimpit. Blok yang ketiga terdapat pada zona empat. Pada zona ini terdapat vegetasi akasia dan cemara udang. Vegetasi akasia memiliki ketinggian 2,5 meter sedangkan cemara memiliki ketinggian kurang dari 1 meter.

Blok keempat terdapat di zona lima dengan vegetasi eksitu yang lebih lebat. Vegetasi tersebut berupa cemara dengan ketinggian 1,5 meter dan juga akasia dengan ketinggian 2,5 meter. Blok di kelima terdapat di zona enam. Pada zona ini terdapat vegetasi penutup berupa akasia dengan ketinggian tiga meter dengan kerapatan tinggi. Pada wilayah ini tidak tampak lagi bentukan gumuk-gumuk melainkan hanya hamparan pasir datar yang bervegetasi. Blok keenam dengan vegtasi cemara dan akasia dengan ketinggian tiga hingga empat meter menempati zona tujuh. Pada daerah ini juga tak nampak kenampakan gumuk-gumuk hanya tertinggal muka gelincir dari barkhanoid. Blok selanjutnya terdapat pada blok gumuk pasir yang masih aktif dengan vegetasi periode tanam baru berupa cemara udang. Cemara udang ini ditanam dengan jarak tanam tiga meter. Masing-masing zona yang menunjukkan blok vegetasi ditunjukkan oleh Gambar 2 berikut ini.

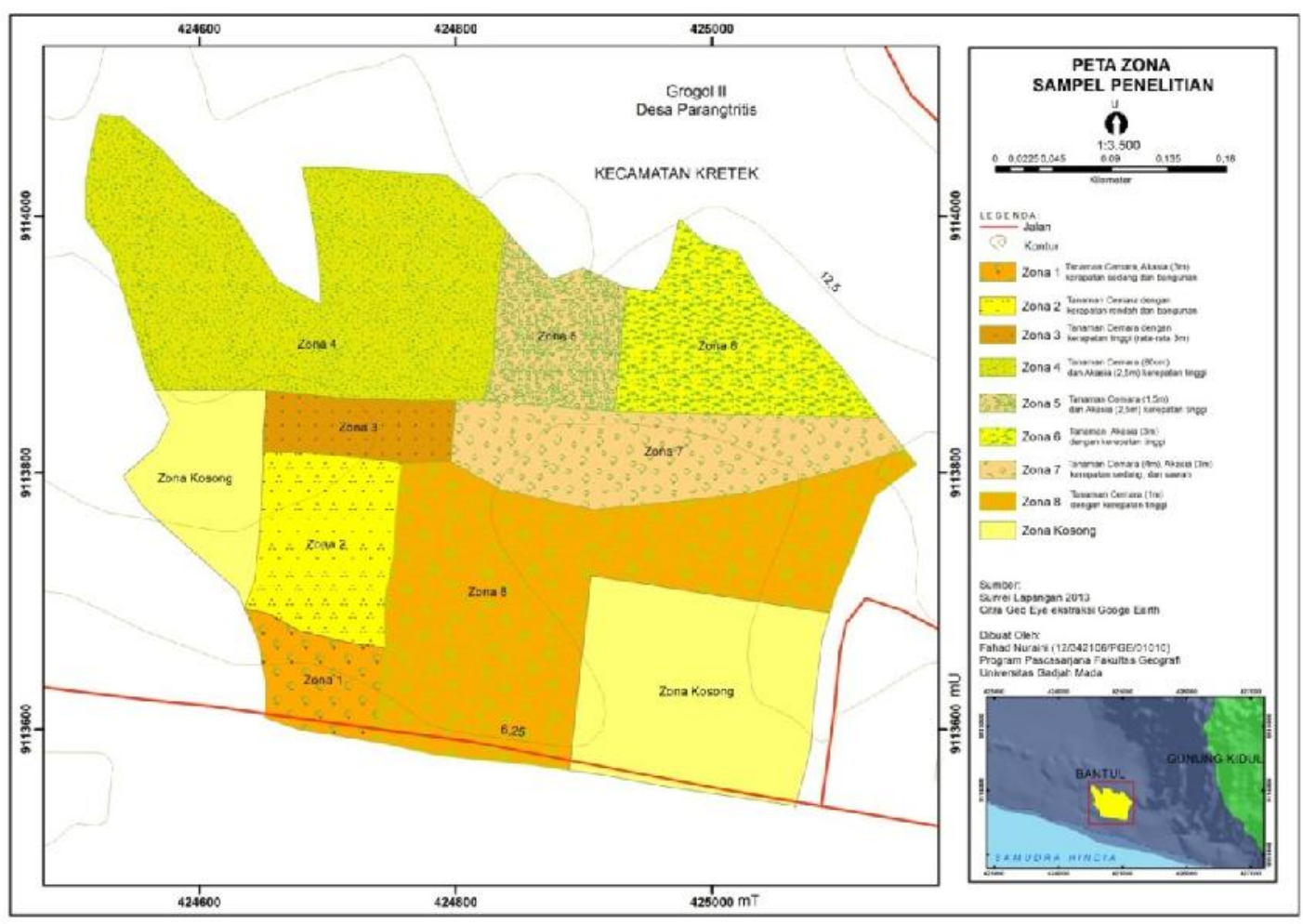

Gambar 2. Sebaran Penghalang berdasarkan zonasi sampling (Sumber: Nuraini, 2016) 
Dalam kaitannya dengan gangguan perkembangan alami gumuk pasir oleh keberadaan vegetasi, kondisi gelembur pasir dapat dijadikan salah satu indikator, khususnya untuk identifikasi tanda-tanda awal kerusakan gumuk pasir sebelum terbentuknya lubang deflasi. Singh (1973) mengemukakan bahwa pada kondisi normal di area tanpa penghalang, gelembur dapat terbentuk sempurna dengan karakteristik gelembur membentuk garis sejajar yang seragam dengan jarak antar gelembur yang sama. Karakteristik gelembur yang terbentuk pada area yang mengalami erosi akibat gangguan berupa penghalang akan cenderung membentuk garis bingkai-bingkai yang saling berpotongan pada ujungnya. Kondisi ini dijumpai di daerah penelitian. Pada daerah yang tak tererosi gelembur membentuk garis-garis sejajar yang jelas dari kaki sampai dengan puncak gumuk pasir, namun pada daerah yang tererosi gelembur pasir berubah bentuk menjadi garis-garis bingkai yang saling berpotongan. Pada daerah yang tererosi di bagian deposisi lubang deflasi tidak terdapat gelembur walaupun daerah deposisi merupakan daerah yang tak bervegetasi.

Perbedaan karakteristik gelembur tersebut merupakan salah satu identifikasi adanya gangguan transpor pasir pada gumuk pasir yang mengakibatkan ketidaknormalan bentukan gelembur. Ketidak normalan gelembur sangat jelas terlihat dari bentuk dan juga jarak. Pada area tererosi memiliki jarak anatar gelembur $>30 \mathrm{~cm}$, sedangkan gelembur pasir yang normal pada area yang tak tererosi memiliki jarak antar gelembur dua hingga lima cm. Berdasarkan uraian klasifikasi Singh (1973) di daerah penelitian terdapat variasi ukuran gelembur pasir yang di tunjukkan pada Tabel 2 dan Gambar 3.

Tabel. 2 Karakteristik Gelembur di Daerah Penelitian

\begin{tabular}{|c|c|c|c|c|}
\hline $\begin{array}{l}\text { Tipe Gumuk } \\
\text { Pasir pada } \\
\text { Zona }\end{array}$ & Gangguan & $\begin{array}{c}\text { Tipe } \\
\text { Gelembur }\end{array}$ & $\begin{array}{l}\text { Ukuran } \\
\text { (J=Jarak antar } \\
\text { gelembur; } \\
\text { T=tinggi) }\end{array}$ & Keterangan \\
\hline $\begin{array}{l}\text { Barkhan (Zona } \\
1 \text { dan 2) }\end{array}$ & $\begin{array}{l}\text { Tanpa } \\
\text { Gangguan }\end{array}$ & $\begin{array}{l}\text { Gelembur } \\
\text { pasir }\end{array}$ & $\begin{array}{l}J=2-3 \mathrm{~cm} \\
T=1-2 \mathrm{~cm}\end{array}$ & $\begin{array}{l}\text { Normal pada badan barkhan tanpa penghalang. } \\
\text { Semakin mendekati muka gelincir ukuran } \\
\text { mengecil dan rapat }\end{array}$ \\
\hline $\begin{array}{l}\text { Badan Barkhan } \\
\text { (Zona } 1 \text { dan 2) }\end{array}$ & Rumah & $\begin{array}{l}\text { Gelembur } \\
\text { butir }\end{array}$ & $\begin{array}{c}\mathrm{J}=>30 \mathrm{~cm} \\
\mathrm{~T}=3 \mathrm{~cm}\end{array}$ & $\begin{array}{l}\text { Erosi pada lubang deflasi memanjang makro. } \\
\text { Kedalaman diukur dari titik tengah perpotongan } \\
\text { cekungan. }\end{array}$ \\
\hline $\begin{array}{l}\text { Melintang } \\
\text { (Zona 8) }\end{array}$ & $\begin{array}{l}\text { Vegetasi } \\
\text { (Cemara < 1m) }\end{array}$ & $\begin{array}{l}\text { Gelembur } \\
\text { pasir }\end{array}$ & $\begin{array}{l}\mathrm{J}=5-10 \mathrm{~cm} \\
\mathrm{~T}=0,5-1 \mathrm{~cm}\end{array}$ & $\begin{array}{l}\text { Erosi pada lubang deflasi memanjang mikro. } \\
\text { Jarak normal gelembur pada bagian yang tidak } \\
\text { terdampak cemara } 5 \mathrm{~cm} \text {, sedangkan pada bagian } \\
\text { yang tererosi berjarak }>5 \mathrm{~cm}-10 \mathrm{~cm} \text {. }\end{array}$ \\
\hline $\begin{array}{l}\text { Memanjang } \\
\text { (Zona 8) }\end{array}$ & $\begin{array}{l}\text { Vegetasi } \\
(\text { Cemara < 1m) }\end{array}$ & $\begin{array}{l}\text { Gelembur } \\
\text { pasir }\end{array}$ & $\begin{array}{c}\mathrm{J}=5 \mathrm{~cm} \\
\mathrm{~T}=0,5-1 \mathrm{~cm}\end{array}$ & Erosi pada lubang deflasi memanjang mikro \\
\hline $\begin{array}{l}\text { Barkhanoid } \\
\text { (Zona 4,5) }\end{array}$ & $\begin{array}{l}\text { Vegetasi } \\
\text { (Cemara dan } \\
\text { akasia }>3 \mathrm{~m})\end{array}$ & $\begin{array}{l}\text { Gelembur } \\
\text { pasir }\end{array}$ & $\begin{array}{c}\mathrm{J}=7 \mathrm{~cm} \\
\mathrm{~T}=0,5-1 \mathrm{~cm}\end{array}$ & $\begin{array}{l}\text { Deposisi sedimen tanpa gelembur yang } \\
\text { merupakan saluran sedimen pada lubang deflasi } \\
\text { palung. Gelmbur terdapat pada sisi luar bingkai }\end{array}$ \\
\hline Zona 5, 6 & $\begin{array}{l}\text { Cemara dan } \\
\text { Aksia > } 3 \mathrm{~m}\end{array}$ & $\begin{array}{l}\text { Tidak } \\
\text { terdapat }\end{array}$ & - & $\begin{array}{l}\text { Erosi intensif dan hanya terdapat deposisi } \\
\text { sedimen tanpa gelembur yang merupakan } \\
\text { saluran sedimen pada lubang deflasi palung. } \\
\text { Gelembur tidak terbentuk juga diakibatkan oleh } \\
\text { seresah yang menutupi permukaan gumuk pasir }\end{array}$ \\
\hline
\end{tabular}

Sumber: Nuraini (2016) 


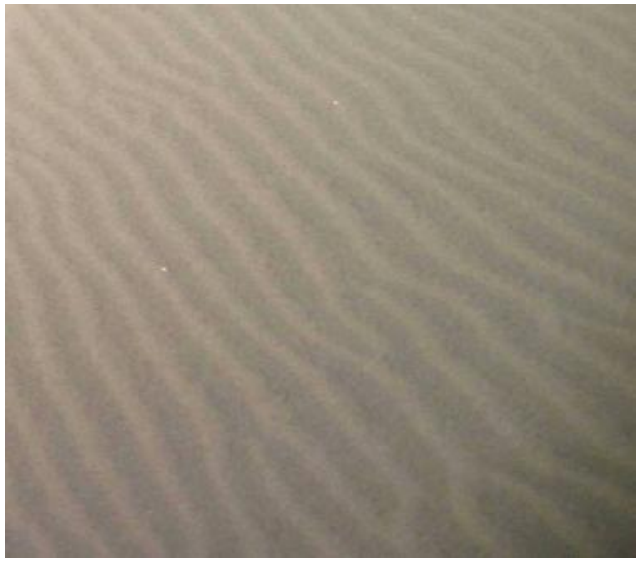

A

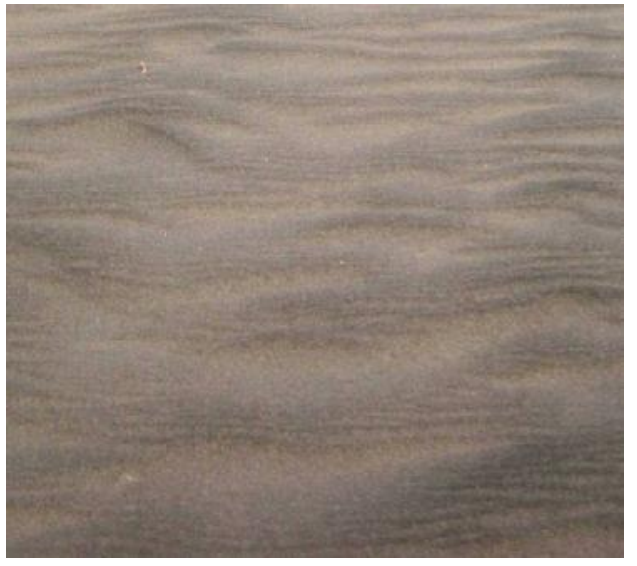

$B$

Gambar 3. Perbandingan Gelembur Pasir Normal pada Barkhan (A) dengan Gelembur Pasir pada Lubang Deflasi Memanjang (B) (Sumber: Nuraini, 2016)

\section{Variasi Kondisi Vegetasi dan Pengaruhnya Terhadap Perkembangan Gumuk Pasir}

Hasil penelitian menunjukkan bahwa vegetasi berpengaruh terhadap perkembangan gumuk pasir yaitu menyebabkan kerusakan pada gumuk pasir. Pengaruh vegetasi dapat dilihat dari beberapa kriteria gangguan pada gumuk pasir antara lain gelembur berubah tipe, terbentuknya lubang deflasi, terjadi pembentukan sedimen erosi. Perbedaan kondisi vegetasi antara vegetasi berkelompok dengan vegetasi tunggal berpengaruh terhadap perbedaan tingkat kerusakan gumuk pasir yang terjadi.

Vegetasi kelompok memiliki pengaruh yang kuat terhadap perubahan gumuk pasir. Vegetasi kelompok dengan ketinggian lebih dari tiga meter dan kerapatan tinggi akan membentuk pematah angin, namun angin masih mampu menerobos sela-sela antar vegetasi, sehingga terbentuk gelembur-gelembur pasir halus (hampir rata tidak terdapat gelembur) dipermukaan gumuk. Gangguan yang sangat menghambat laju pasir di permukaan gumuk yaitu bila vegetasi berkanopi lebat, sehingga seresah daun yang jatuh memenuhi permukaan gumuk yang pada akhirnya menyebabkan permukaan tertutup gumuk dan ditumbuhi oleh semak. Apabila permukaan gumuk sudah tertutup oleh semak maka proses deflasi berhenti karena pasir tidak dapat tertranspor dan terjadi perataan permukaan gumuk pasir. Kanopi yang rapat juga menghamburkan sedimen pasir didepan penghalang sehingga angin yang melaju mengrosi daerah belakang dan membentuh hantaman angin sehingga mengerosi didnding atau badan gumuk pasir dibelakangnya. Evolusi atau perubahan gumuk pasir berlangsung secara bertahap seiring pertumbuhan vegetasi.

Vegetasi tunggal memiliki pengaruh paling lebih kecil dibandingkan dengan vegetasi kelompok. Hal ini dikarenakan vegetasi tunggal memiliki morfologi batang atau semak dengan bentuk yang ramping. Vegetasi tunggal juga memiliki dampak pada transpor pasir dibelakangnya, pematah angin berupa vegetasi tungggal ini mengakibatkan angin yang melaju dengan membawa pasir akan berbelok kekanan dan kiri vegetasi dan bertemu kembali di belakang vegetasi, sehingga membentuk sedimen lidah dibelakang vegetasi selain itu juga terbentuk lubang deflasi cawan dibelakang vegetasi. Vegetasi 
tunggal tidak mempengaruhi gelembur pasir disekitarnya yang terpengaruh hanya di belakang vegetasi, sehingga apabila laju angin dan pasir lebih kuat maka vegetasi tidak mampu lagi menghalangi laju pasir dan vegetasi tersebut akan tertimbun oleh pasir. Tabel 3 dan Tabel 4 menunjukkan perbedaan pengaruh antara vegetasi kelompok dan vegetasi tunggal terhadap perkembangan gumuk pasir.

Selain vegetasi kelompok dan vegetasi tunggal sebenarnya terdapat satu jenis penghalang lain yang juga berpengaruh terhadap kerusakan gumuk pasir yaitu bangunan. Bangunan khususnya rumah memiliki pengaruh yang jauh lebih besar dibandingkan dengan vegetasi kelompok ataupun vegetasi tunggal. Hal ini dikarenakan rumah dapat mengubah bentukan gumuk pasir dengan cepat. Hasil pengamatan lapangan juga menunjukkan bahwa kehadiran rumah secara tiba-tiba pada area lapang di gumuk pasir merupakan faktor utama yang menyebebkan perubahan yang cepat.

Tabel 3. Pengaruh Penghalang terhadap Kerusakan Gumuk Pasir

\begin{tabular}{|c|c|c|c|c|c|c|c|}
\hline \multirow{2}{*}{$\begin{array}{c}\text { Jenis } \\
\text { vegetasi }\end{array}$} & \multicolumn{2}{|c|}{ Gelembur } & \multicolumn{2}{|c|}{ Lubang deflasi } & \multicolumn{2}{|c|}{ Sedimen Lidah } & \multirow[t]{2}{*}{ Keterangan } \\
\hline & $\mathrm{Ya}$ & Tidak & $\mathrm{Ya}$ & Tidak & $\mathrm{Ya}$ & Tidak & \\
\hline $\begin{array}{l}\text { Vegetasi } \\
\text { tunggal }\end{array}$ & - & V & V & - & V & - & $\begin{array}{l}\text { 1. Gelembur masih bertipe gelembur pasir } \\
\text { 2. Lubang deflasi cawan mikro (pada } \\
\text { vegetasi semak dan vegetasi eksitu }<1 \mathrm{~m} \text { ) } \\
\text { 3.sedimen lidah mmembentuk punggungan } \\
\text { dengan bentukan lidah memanjang ukuran } \\
\text { sesuai dengan tinggi vegetasi } \\
\text { 4. proses erosi dinding }\end{array}$ \\
\hline $\begin{array}{l}\text { Vegetasi } \\
\text { kelompok }\end{array}$ & - & - & V & - & V & - & $\begin{array}{l}\text { 1. Gelembur tidak ada karena tertutup oleh } \\
\text { sedimen yang terhamburkan (pada vegetasi } \\
\text { dengan kerapatan tinggi) } \\
\text { 2. proses perataan badan } \\
\text { 3. lubang deflasi terbentuk palung karena } \\
\text { loncatan angin dengan vegetasi rapat }\end{array}$ \\
\hline
\end{tabular}

Sumber: Nuraini (2016)

Tabel 4. Pengaruh dari vegetasi kelompok (A) dan vegetasi tunggal (B) terhadap proses geomorfologi yang menimbulkan kerusakan gumuk pasir

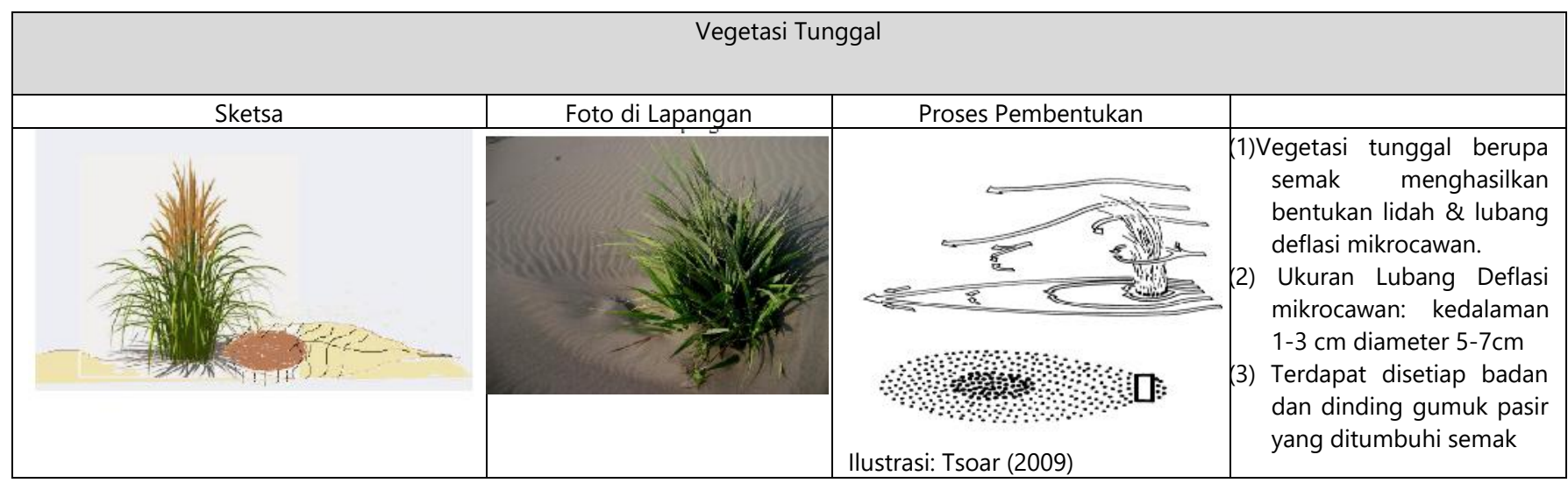




\begin{tabular}{|c|c|c|c|}
\hline$\sqrt{6}$ & 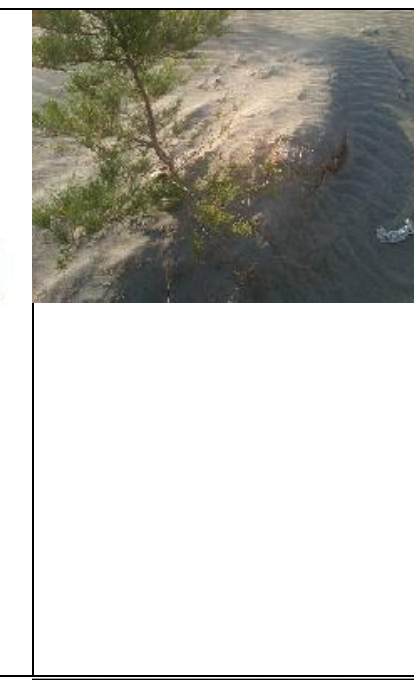 & 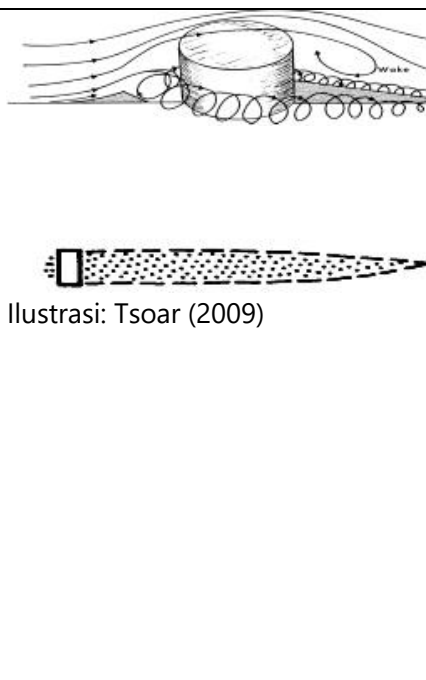 & $\begin{array}{l}\text { Vegteasi tunggal cemara } \\
<1 \mathrm{~m} \text { menghasilkan } \\
\text { bentukan lidah \& lubang } \\
\text { deflasi memanjang mikro } \\
\text { (2) Ukuran Lubang bentukan } \\
\text { lidah kurang lebih sama } \\
\text { dengan tinggi pohon, dan } \\
\text { ukuran lubang deflasi } \\
\text { mikro dibelakangnya } \\
\text { membentuk parit kecil } \\
\text { dengan jarak gelembur } 5- \\
10 \mathrm{~cm} \& \text { material pasir } \\
\text { lebih kasar. Lebar 15-30 } \\
\mathrm{cm} \text { (3) Terdapat disetiap badan } \\
\text { gumuk pasir yang } \\
\text { terdapat vegetasi eksitu } \\
<1 \mathrm{~m}\end{array}$ \\
\hline  &  & . & $\begin{array}{l}\text { Vegetasi tunggal siwalan } \\
\text { dengan ketinggian } 16 \mathrm{~m} \\
\text { membentuk bentukan lidah } \\
\text { dengan ukuran morfometri } \\
\text { dengan ketinggian } 13,20 \\
\text { meter, lebar } 23 \text { meter, } \\
\text { kemiringan muka gelincir } \\
68 \% \text {, dan panjang } 95 \text { meter. }\end{array}$ \\
\hline \multicolumn{4}{|c|}{ Vegetasi Kelompok } \\
\hline Ilustrasi cekungan: Hesp (2002) & 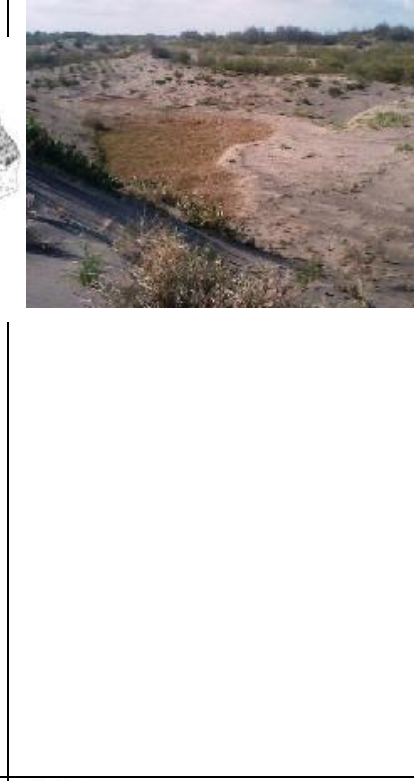 & $\stackrel{M}{\longrightarrow}$ & $\begin{array}{l}\text { (1) Kelompok cemara dengan } \\
1 \text {-2m membentuk lubang } \\
\text { deflasi cawan dan } \\
\text { semicawan } \\
\text { (2) Morfometri cawan } \\
\text { kedalaman } 1 \mathrm{~m} \text { dengan } \\
\text { diameter } 5 \mathrm{~m} \text {. } \\
\text { (3) Morfometri semipalung } \\
\text { kedalaman } 2-5 \mathrm{~m} \text { dan } \\
\text { panjang sumbu } 30-50 \mathrm{~m} \text {. } \\
\text { (4) vegetasi kelompok dengan } \\
\text { ukuran } 1-2 \mathrm{~m} \text { masih } \\
\text { memberikan ruang untuk } \\
\text { proses deflasi namun } \\
\text { gangguan yang terjadi } \\
\text { yaitu terbenuknya lidah } \\
\text { pada setiap belakang } \\
\text { vegetasi dan juga alur } \\
\text { lubang deflasi } \\
\text { memanjang mikro yang } \\
\text { mengubah gelembur }\end{array}$ \\
\hline llustrasi cekungan: Hesp (2002) & 3 & & 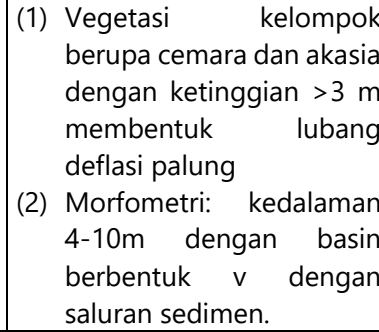 \\
\hline
\end{tabular}




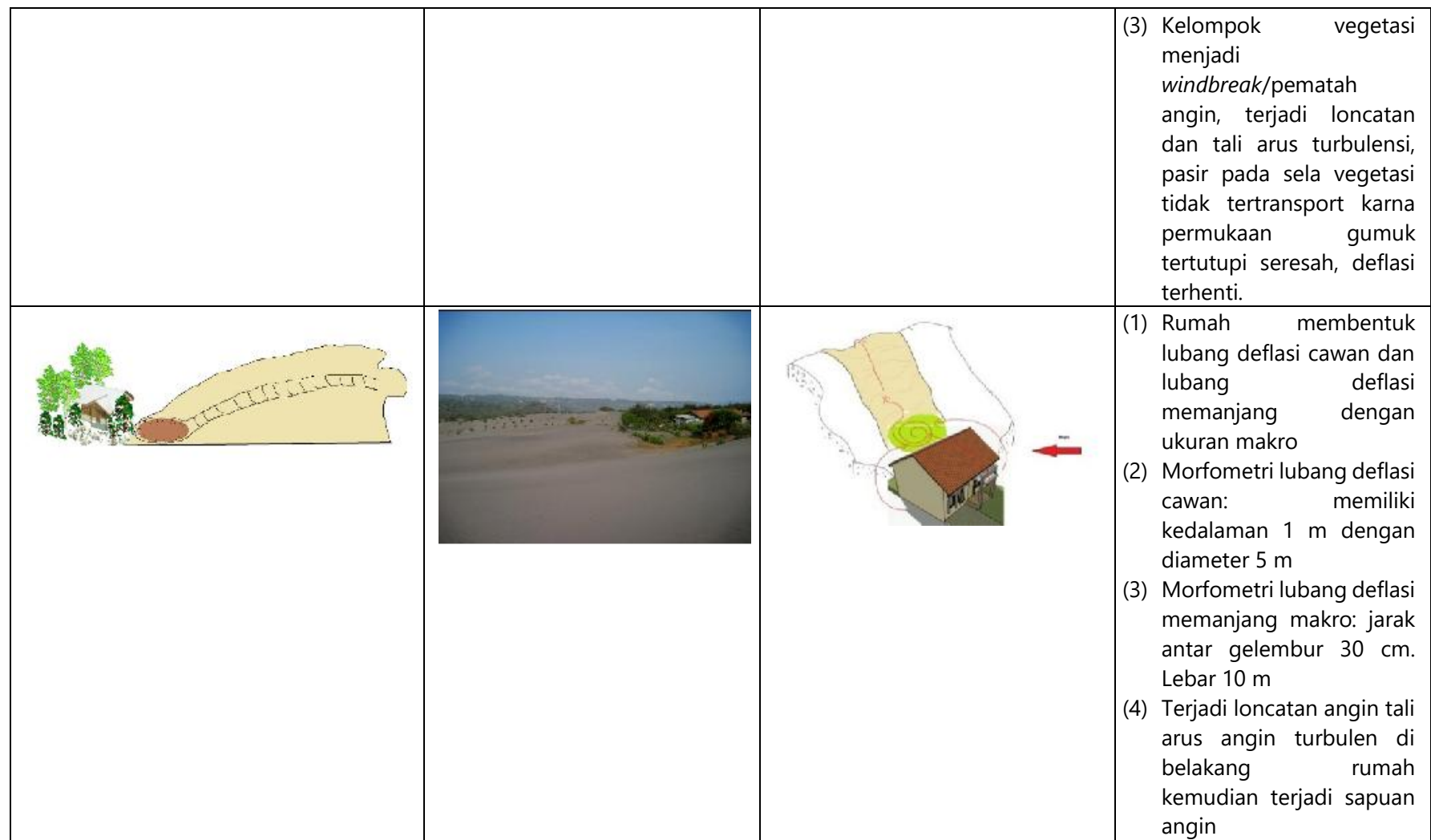

Sumber: Nuraini (2016)

\section{SIMPULAN}

Berdasarkan hasil penelitian dapat disimpulkan bahwa:.

1. Gumuk pasir merupakan bentuk lahan yang kompleks dengan factor pembentuk yang saling bersinergi berupa kondisi lingkungan, angin, dan pasokan pasir. Apabila salah satu faktor terganggu maka terjadi dinamika perkembangan yang tidak normal yang mengakibatkan fiksasi

2. Vegetasi memiliki pengaruh kuat terhadap dinamika perkembangan gumuk pasir, vegtasi di lingkungan gumuk yang tenggar sehingga vegetasi berperan sebagai penghalang angina dan laju pasir pada proses deflasi.

3. Seiring pertumbuhan vegtasi maupun bangunan lainnya juga akan mempengaruhi perubahan mofologi.

\section{UCAPAN TERIMA KASIH}

Data-data yang digunakan dalam tulisan ini merupakan bagian dari penelitian tesis yang dilaksanakan dengan judul Geomorfometri Lubang Deflasi pada Lorong Angin Alami Gumuk Pasir Aeolian di Pesisir Parangkusumo Kabupaten Bantul Daerah Istimewa Yogyakarta, di Fakultas Geografi Universitas Gadjah Mada. Penulis mengucapkan terima kasih yang sebesar-besarnya kepada para pembimbing, serta berbagai pihak yang telah membantu dalam proses pengambilan data, analisis data, serta penyusunan peta hasil penelitian ini. 


\section{DAFTAR PUSTAKA}

Goldsmith, V. 1985. Coastal Dunes, dalam Davis, R.A. (ed) 1985. Coastal Sedimentary Environments. New York: Springer-Verlag.

Hesp, P.A. 2002. Foredune and Blowout: Initiation, Geomorphology and Dynamics. Geomorphology Vol 48: 245-268.

Hesp, P.A. 2008. Coastal Dune in the Tropics and Temperate Region: Location, Formation, Morphology and Vegetation Process, dalam Martinez, L.M. dan Psuty, P.N. (ed). 2008. Coastal Dune Ecology and Conservation. Berlin: Springer.

Kidd, R. 2001. Coastal Dune Management a Manual of Coastal Dune Management and Rehabilitation Techniques. Newcastle: NSW Goverment.

Nuraini, F. 2016. Geomorfometri Lubang Deflasi pada Lorong Angin Alami Gumuk Pasir Aeolian di Pesisir Parangkusumo Kabupaten Bantul Daerah Istimewa Yogyakarta, di Fakultas Geografi Universitas Gadjah Mada. Tesis. Program Pascasarjana Universitas Gadjah Mada.

Pina, G.G., Perez, J.J.M., Ramirez, J.L., dan Ley, C. 2002. Sand Dune Management Problem and Techniques. Journal of Coastal Research Vol 36: 325-332.

Singh. 1973. Depositional Sedimentary Environments. New York: Springer.

Sunarto. 2014. Geomorfologi dan Kontribusinya dalam Pelestarian Pesisir Bergumuk Pasir Aeolian dari Ancaman Agrogenik dan Urbanogenik. Pidato pengukuhan Jabatan Guru Besar, pada Fakultas Geografi, Universitas Gadjah Mada. Universitas Gadjah Mada 2 April 2014.

Pye, K. dan Tsoar, H. 2009. Aeolian Sand and Sand Dunes. Berlin: Springer Verlag.

Winarni, WW., Atmanto, W.D., Danarto, S. 2012. Peran Wind Barrier Cemara Udang (Casuarina equisetifolia var. Incana) dalam Agroforestri Pesisir. Prosiding. Seminar Nasional Agroforestri III, 29 Mei 2012 HIm: 245-248 